\title{
Toxicity Effects of Selected Heavy Metals on Lactuca sativa and Hydra viridissima used for Sustainable Crop Production
}

\author{
Lina María Cáceres Díaz \\ Microbiology Department, Javeriana University, Bogota, Colombia \\ E-mail: cacereslina@ hotmail.com \\ Claudia Campos \\ Microbiology Department, Javeriana University, Bogota, Colombia \\ E-mail: campos@javeriana.edu.co
}

Gideon Oron (Corresponding author)

Zuckerberg Institute for Water Research, The Jacob Blaustein Institutes for Desert Research, Ben-Gurion University of the Negev, Kiryat Sde-Boker, 8499000, Israel

The Department of Industrial Engineering and Management and the Environment Engineering Program, Ben-Gurion University of the Negev, Beer-Sheva, 8410500, Israel E-mail: gidi@bgu.ac.il

Received: June 4, 2018 Accepted: June 18, 2018 Published: July 30, 2018

doi:10.5296/emsd.v7i3.13446 URL: https://doi.org/10.5296/emsd.v7i3.13446

\begin{abstract}
This study examines the prospects for using Hydra viridissima toxicity test $96-\mathrm{h} \mathrm{LC}_{50}$, served as a model invertebrate, Lactuca sativa $\mathrm{L}$. was applied for seeds toxicity test (120-h $\left.\mathrm{IC}_{50}\right)$ and a model plant for an acute toxicity assessment of heavy metals content in water. The heavy metals used to assess the acute toxicity of the water utilized for agricultural irrigation in arid regions includes cadmium $\left(\mathrm{CdCl}_{2} \cdot 2 \mathrm{H}_{2} \mathrm{O}\right)$, chromium $\left(\mathrm{K}_{2} \mathrm{Cr}_{2} \mathrm{O}_{7}\right)$, zinc $\left(\mathrm{ZnSO}_{4} \cdot 7 \mathrm{H}_{2} \mathrm{O}\right)$, and boron $\left(\mathrm{H}_{3} \mathrm{BO}_{3}\right)$. A grading of the substances was conducted, and it was found that the toxicity levels for $H$. viridissima and L. sativa were, with the least harmful first: $\mathrm{B}<\mathrm{Cr}<\mathrm{Zn}<\mathrm{Cd}$ and $\mathrm{Zn}<\mathrm{B}<\mathrm{Cr}<\mathrm{Cd}$, respectively. Results indicate that $H$. viridissima was a more sensitive
\end{abstract}


indicator of toxicity for all of the evaluated substances. However, L. sativa could also be used successfully to rank toxicants in order of their potential hazards.

Keywords: Acute toxicity, Heavy metals, Hydra viridissima, Lactuca sativa

\section{Introduction}

Reuse of treated wastewater is a common and rapidly increasing practice, mainly in arid and semi-arid regions around the world. The treated wastewater serves as a "new" extra resource, which is added to the water balance and substitutes for conventional water in agricultural irrigation. Israel is presently reusing more than $65 \%$ of its total municipal wastewater production, and it plans to reach more than 90\% reuse during the next decade (Han et al., 2016; Reznik et al., 2017). The contamination of agricultural lands and irrigation water with toxic pollutants such as inorganic contaminants poses an environmental risk to humans and animals. Heavy metals, including nickel, zinc, cadmium, chromium, copper and cobalt, may accumulate naturally in soil or may originate from industrial and mining processes (Murch et al., 2003; El-Nahhal, 2003; Bigalke et al., 2018). Furthermore, heavy metals contamination of aquatic ecosystems in Egypt (e.g. lead, cadmium, chromium, zinc, copper, manganese and iron) has been receiving increased worldwide attention (Khan et al., 2013; Taghizadeh et al., 2017; Bigalke et al., 2018). Contamination refers primarily to fish, which are often at the top of the aquatic food chain and may concentrate large amounts of some metals from the water (Buchet and Lison, 2000). For example, cadmium and mercury injure the kidneys and cause symptoms of chronic toxicity, including impaired kidney function, poor reproductive capacity, hypertension, tumors and hepatic dysfunction. Lead causes renal failure and liver damage. Other metals, such as chromium, zinc and copper, cause nephritis, anuria and extensive lesions in the kidney (Mansour and Sidky, 2002).

Therefore, a multispecies approach towards ecotoxicological testing is fundamental for improving environmental management and ecological risk assessment in arid regions. Plant and animal communities are diverse in composition and in their sensitivity to toxicants (Kovačević1 et al., 2007). Thus, a battery of bioassays rather than a single species assay is used in toxicity evaluation, representing the range of sensitivities of field organisms. In this context, the use of plants L. sativa, offers and advantage over other organisms, since they can be more sensitive to environmental stress, are easy manipulated and stored, and furthermore, they offer a low-cost and good correlation in contrast with other bioassays (Escoto et al., 2007). On the other hand, H. viridissima (a monecious species, distinctively green due to its symbiotic green algae) has been reported to show high sensitivity to different heavy metals compared to other species of Hydra (Karntanut and Pascoe, 2002).

The purpose of this study was to investigate toxicity effects of cadmium $\left(\mathrm{CdCl}_{2} \cdot 2 \mathrm{H}_{2} \mathrm{O}\right)$, chromium $\left(\mathrm{K}_{2} \mathrm{Cr}_{2} \mathrm{O}_{7}\right)$, zinc $\left(\mathrm{ZnSO}_{4} .7 \mathrm{H}_{2} \mathrm{O}\right)$, and boron $\left(\mathrm{H}_{3} \mathrm{BO}_{3}\right)$ on (Lactuca sativa $\mathrm{L}$.) as a plant model as well as on the lethality of the green Hydra, Hydra viridissima as an aquatic animal model. It allows studying future approaches applied for evaluating the toxicity risk assessment of water used for agricultural irrigation in arid regions. It enabled as well to compare toxicity and sensitivities of different compounds especially for boron. This element is an essential nutrient for plants however, above certain concentrations (approximately 0.4 


\section{Ml Macrothink}

$\mathrm{mg} / \mathrm{L}$ ) can be toxic to aquatic and terrestrial organisms (Butterwick et al., 1989).

\section{Materials and Methods}

\subsection{Laboratory Culture and Maintenance of H. viridissima}

The green Hydra used in toxicity tests were donated by The Hebrew University of Jerusalem, Israel (Dr. E. Zlotkin, Dept. of Cell and Animal Biology). The animals were cultured in a Hydra medium "M" comprising $1.0 \mathrm{mM}$ calcium chloride, $1.0 \mathrm{mM}$ sodium hydrogen carbonate, $0.1 \mathrm{mM}$ potassium chloride and 0.1 magnesium chloride (Lenhoff, 1983). The $\mathrm{pH}$ of the Hydra medium was adjusted to 7.6-7.8 with HCl. Hydra stocks were kept in circular glass culture bowls (20 cm diameter), two-thirds full with the Hydra medium. Hydra stock cultures were kept at room temperature $\left(24^{\circ} \mathrm{C} \pm 0.1^{\circ} \mathrm{C}\right)$, under a standard 16:8 h light: dark photoperiod and a light intensity of 800 lux (Beach and Pascoe, 1998; U.S. EPA, 2002). The Hydra was fed daily with freshly hatched iodine-disinfected Artemia salina nauplli (brine shrimp) for at least $30 \mathrm{~min}$, after which the bowls were cleaned and the water replaced. Once a week or when necessary, the Hydra were inserted into clean aquaria. Hydra were acclimatized in dilution media (synthetic moderately hard water: U.S. EPA, 2002; APHA, 2012) and starved for $24 \mathrm{~h}$ prior to the start of the toxicity tests.

\subsection{Procedure for the Acute Toxicity Tests for H. Viridissima}

Acute toxicity tests for $H$. viridissima with each of the test compounds were performed based on the technical methodology of the microplate-based Hydra attenuata assay (Blaise and Jean-Francois, 2005; Traesel et al., 2014; Murphy and Quinn, 2018). The 96-h static toxicity tests were carried out in 12-well microplates (Falcon \#3043). Three non-budding Hydra $\times 3$ replicates were randomly placed into each test well containing $4 \mathrm{~mL}$ of each serial dilution or dilution media (control). All the experiments were carried out under the same environmental conditions as the Hydra culture. Changes in $H$. viridissima morphology were observed after $24,48,72$, and $96 \mathrm{~h}$ of exposure using a stereomicroscope at 6-10 x magnification Figure 1. However, only the effect of $96 \mathrm{~h}$ of exposure was considered. The tulip and disintegration stages were used as toxicity endpoints to estimate the median lethal concentration (96-h $\mathrm{LC}_{50}$ ) values in the definitive toxicity tests.

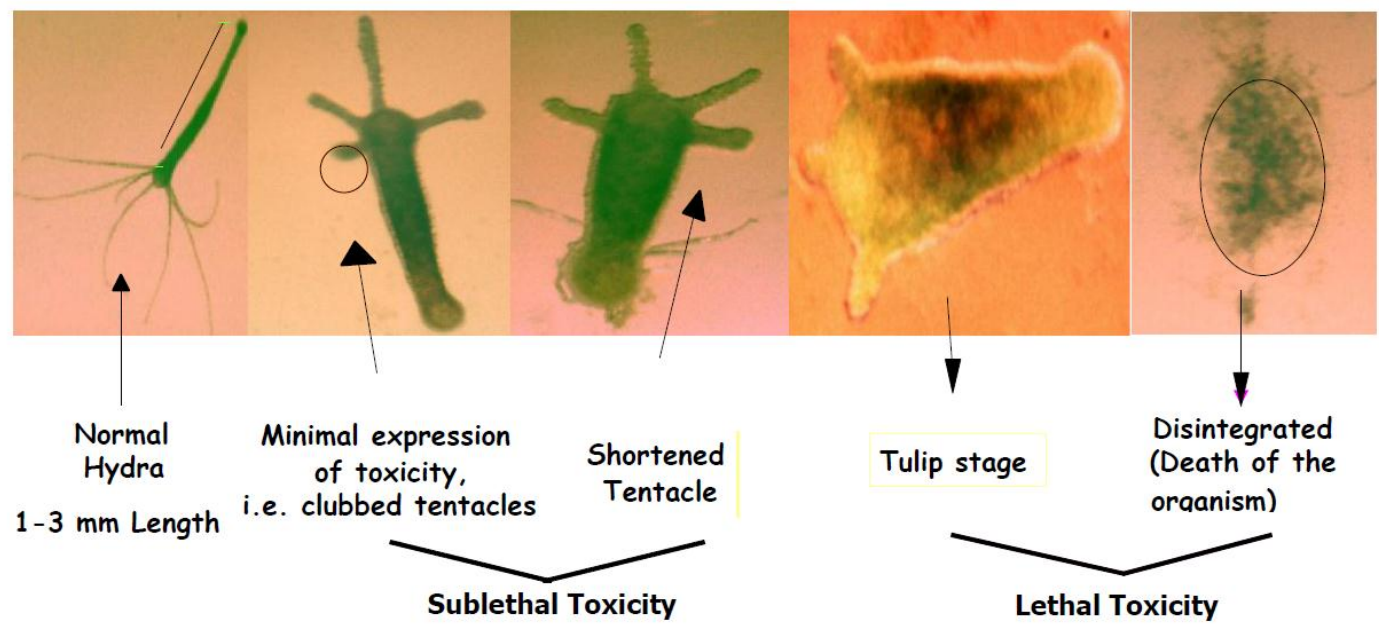




\section{$\triangle$ Macrothink}

Figure 1. Light stereomicroscope photographs: (6 to $10 \mathrm{x}$ magnification) of the morphological changes in Hydra viridissima exposed to a toxic event. Sublethal and lethal toxicity endpoints were respectively determined from the "clubbed tentacle" and "tulip" stages. Normal Hydra; clubbed tentacles, shortened tentacles, tulip stage, disintegration (photos taken during the experimental period)

\subsection{Procedure for the Toxicity Tests for L. sativa}

The acute toxicity tests of $L$. sativa for each of the test compounds were conducted according to the procedures used at the National Water Research Institute (NWRI) (Sherry et al., 1997; Traesel et al., 2014). In this study, commercial L. sativa L. seeds were used (the same seed batch was used for the duration of the experiment and was stored in a refrigerator at $4{ }^{\circ} \mathrm{C}$ until the tests were performed). In the static short-term root elongation toxicity tests, 20 seeds of similar size, shape and color were placed on Whatman No. 3 filter paper in a Petri dish containing 6-7 ml of the test solution. Incubation was for a period of $120 \mathrm{~h}(5 \mathrm{~d})$ at room temperature $\left(24 \pm 0.1^{\circ} \mathrm{C}\right)$, in darkness. After germination, the seedlings were removed, and millimeter paper was used to measure the root growth for each of the 20 seedlings in all the concentrations evaluated (one replicate per concentration), and in the control used in each toxicity test. The mean root growth rate with standard deviation was calculated for the control and for the 20 seeds in each test. With the average root growth of each concentration, the percentage of growth inhibition used as an endpoint was determined and then compared to the average root growth of the control (Sherry et al., 1997). The data found was used to estimate the concentration that produces $50 \%$ inhibition $\left(120-\mathrm{h} \mathrm{IC}_{50}\right)$ in the definitive toxicity tests. The average root growth length of the control seedlings was $20.9 \mathrm{~mm}$ (S.D. \pm 3.10 ).

\subsection{Toxicant Test Preparation}

Test compounds were cadmium chloride $\left(\mathrm{CdCl}_{2} \cdot 2 \mathrm{H}_{2} \mathrm{O}\right)$, hexavalent chromium $\left(\mathrm{K}_{2} \mathrm{Cr}_{2} \mathrm{O}_{7}\right)$, zinc sulfate $\left(\mathrm{ZnSO}_{4} .7 \mathrm{H}_{2} \mathrm{O}\right)$ and boric acid $\left(\mathrm{H}_{3} \mathrm{BO}_{3}\right)$. All the stock solutions were prepared by dissolving reagents grade compounds in doubly distilled water $\left(\mathrm{ddH}_{2} \mathrm{O}\right)$ (US EPA, 2002), without $\mathrm{pH}$ adjustment according to Canadian practice in definitive regulatory tests (EPS, 1999), and confirmed by atomic absorption spectrometry. Synthetic moderately hard water was used as a control (without metal) in all toxicity tests, and as the dilution media for the preparation of the test concentrations (US EPA, 2002; APHA, 2012). The water quality (hardness, alkalinity, conductivity, and $\mathrm{pH}$ of the synthetic moderately hard water) and the $\mathrm{pH}$ of the toxic solutions were also measured throughout the study using standard procedures (Table 1).

Table 1. Water quality of synthetic moderately hard water and $\mathrm{pH}$ of the stock solutions for toxicity tests with Hydra viridissima and Lactuca sativa

\begin{tabular}{|c|c|}
\hline Parameter & Measurement ( \pm S. D.) \\
\hline Hardness of moderately hard water ( \pm S.D.) & $170.3( \pm 0.25)^{\mathrm{a}} \mathrm{mg} / \mathrm{L}$ as $\mathrm{CaCO}_{3}$ \\
\hline Alkalinity of moderately hard water ( \pm S.D.) & $117.1( \pm 3.86)^{\mathrm{a}} \mathrm{mg} / \mathrm{L}$ as $\mathrm{CaCO}_{3}$ \\
\hline Conductivity of moderately hard water ( \pm S.D.) & $545( \pm 70.7)^{\mathrm{a}} \mu \mathrm{S} \mathrm{cm}^{-1}$ \\
\hline pH of moderately hard water ( \pm S.D.) & $7.44( \pm 0.29)^{\mathrm{a}}$ \\
\hline
\end{tabular}




\begin{tabular}{|l|l|}
\hline $\mathrm{pH}$ of cadmium stock solution & $4.8^{\mathrm{b}}$ \\
\hline $\mathrm{pH}$ of zinc stock solution & $4.4^{\mathrm{b}}$ \\
\hline $\mathrm{pH}$ of chromium stock solution & $4.7^{\mathrm{b}}$ \\
\hline $\mathrm{pH}$ of boron stock solution & $4.4^{\mathrm{b}}$ \\
\hline
\end{tabular}

${ }^{\text {a }}$ Each value represents the mean \pm S.D. of $n=12$ replicates.

${ }^{\mathrm{b}}$ The stock solutions were prepared by dissolving reagents in doubly distilled water, without $\mathrm{pH}$ adjustment

2.5 Acute Toxicity Range-finding Tests and the Definitive Acute Toxicity Tests for Hydra viridissima and - Lactuca sativa

Preliminary acute toxicity range-finding tests were performed to establish the concentration intervals adequate for determining the 96-h $\mathrm{LC}_{50} \mathrm{~s}$ and $120-\mathrm{h} \mathrm{IC}_{50} \mathrm{~s}$ in the full-scale definitive toxicity tests for $H$. viridissima and $L$. sativa respectively (US EPA, 2002). After screening the range-finding tests, 20 acute toxicity tests (20 replicates) were performed for each compound in each organism (H. viridissima and L. sativa) (US EPA, 2002). The reference toxicant cadmium chloride (US EPA, 2002) was used as a standard during toxicity testing to ensure the sensitivity of Hydra viridissima and Lactuca sativa. The reference toxicant experiment was run in tandem with the chromium $\left(\mathrm{K}_{2} \mathrm{Cr}_{2} \mathrm{O}_{7}\right)$, zinc $\left(\mathrm{ZnSO}_{4} .7 \mathrm{H} 2 \mathrm{O}\right)$, and boron $\left(\mathrm{H}_{3} \mathrm{BO}_{3}\right)$ experiments at the calculated $96-\mathrm{h} \mathrm{LC}_{50}$ and $120-\mathrm{h} \mathrm{IC}_{50} \mathrm{~s}(2.59 \mathrm{mg} / \mathrm{L}$ for L. sativa and $0.002 \mathrm{mg} / \mathrm{L}$ for green hydra) to ensure that the sensitivity of both the Hydra viridissima and the L. sativa did not change with time (Table 2) 


\section{Macrothink}

Environmental Management and Sustainable Development

ISSN 2164-7682

2018, Vol. 7, No. 3

Table 2. Preliminary and final concentrations of Cadmium, Chromium, Zink and Boron for the acute toxicity tests on Hydra viridissima and Lactuca sativa

\begin{tabular}{|c|c|c|c|c|}
\hline Organism & Compound & $\begin{array}{c}\text { Stock solution } \\
(\mathrm{mg} / \mathrm{L})\end{array}$ & $\begin{array}{c}\text { Preliminary } \\
\text { Concentration }(\mathrm{mg} / \mathrm{L})\end{array}$ & $\begin{array}{c}\text { Final Concentration } \\
(\mathrm{mg} / \mathrm{L})\end{array}$ \\
\hline L. sativa & $\mathrm{Cd}^{2+}$ & 100 & $\begin{array}{c}1.0,2.50,5.0,10.0 \\
25.0,50.0,75.0\end{array}$ & $\begin{array}{c}1.0,2.50,5.0 \\
10.0,50.0\end{array}$ \\
\hline L. sativa & $\mathrm{Cr}^{6+}$ & 100 & $\begin{array}{c}1.0,2.50,5.0,10.0 \\
25.0,50.0,75.0\end{array}$ & $\begin{array}{c}5.0,10.0,25.0 \\
50.0,75.0\end{array}$ \\
\hline L. sativa & $\mathrm{Zn}^{2+}$ & 100 & $\begin{array}{c}\text { 1.0, 2.50, 5.0, 10.0, 25.0 } \\
50.0,75.0,100.0\end{array}$ & $\begin{array}{l}25.0,50.0 \\
75.0,100.0\end{array}$ \\
\hline L. sativa & $\mathrm{B}^{3+}$ & 100 & $10.0,25.0,50.0,75.0,100$ & $10.0,25.0,50.0,75.0$ \\
\hline H. viridissima & $\mathrm{Cd}^{2+}$ & 1 & $\begin{array}{c}0.001,0.005,0.010,0.025 \\
0.050 \\
0.10,0.25,0.50,0.75,1.0\end{array}$ & $\begin{array}{c}0.001,0.005 \\
0.010,0.025,0.050\end{array}$ \\
\hline H. viridissima & $\mathrm{Cr}^{6+}$ & 1 & $\begin{array}{c}0.001,0.005,0.01,0.02, \\
0.10,0.20,1.0\end{array}$ & $\begin{array}{c}0.20,0.25,0.50 \\
0.75,1.0\end{array}$ \\
\hline H. viridissima & $\mathrm{Zn}^{2+}$ & 100 & $\begin{array}{c}0.02,0.05,0.10,0.20,0.50,1.0 \\
2.5,5.0,10.0,25.0,50.0,75.0\end{array}$ & $\begin{array}{c}0.02,0.05,0.10 \\
0.20,0.50 \\
\end{array}$ \\
\hline H. viridissima & $\mathrm{B}^{3+}$ & 1 and 100 & $\begin{array}{c}\text { First set: } 0.001,0.005,0.010 \\
0.025 \\
0.050,0.10,0.25,0.50,0.75 \\
\text { Second set: } 5.0,10.0,25.0 \\
50.0,75.0\end{array}$ & $\begin{array}{l}5.0,10.0,25.0 \\
50.0,75.0\end{array}$ \\
\hline
\end{tabular}

\section{Results}

\subsection{Data and Tools Utilized}

The mean percentage effect ( $\%$ of inhibition and lethality for L. sativa and $H$. viridissima, respectively), standard deviations (S.D.), confidence intervals associated with $P<5 \%$ (C.I., or $95 \%$ confidence limits) and variation coefficients were calculated in accordance with standard procedures (U.S. EPA, 2002). The U.S. EPA Probit program, version 1.5, was used to calculate the 96-h $\mathrm{LC}_{50}$ and $120-\mathrm{h} \mathrm{IC}_{50}$ values for $H$. viridissima and L. sativa, respectively (U.S. EPA, 2002). Additionally, warning charts for tests with reference toxicants were plotted using SigmaPlot ${ }^{\circledR}$ graphic software to evaluate the sensitivity of $H$. viridissima and L. sativa, respectively (EPS 1999: U.S. EPA2002). For each species, a one-way analysis of variance (ANOVA) was used to determine differences between the mean values of the $96-\mathrm{h} \mathrm{LC}_{50}(H$. viridissima) or $120-\mathrm{h} \mathrm{IC}_{50}$ (L. sativa) of the four toxic compounds evaluated for each organism (Statistica 6.0 software). When the ANOVA identified a significant difference $(P \leq$ 0.05), a post hoc pairwise comparison of sample means was performed with Tukey's honestly significant difference test (Statistica 6.0 software). 
3.2 Results of the Preliminary Acute Toxicity Range-finding Test for H. viridissima

The preliminary results for $H$. viridissima exposed to cadmium show that $100 \%$ lethality occurred at concentrations between 0.010 and $1.0 \mathrm{mg} / \mathrm{L}$, and at concentrations of 0.001 and $0.005 \mathrm{mg} / \mathrm{L}$, lethality was $44 \%$ and $66 \%$, respectively. The final concentration range defined for the final acute toxicity experiments for $\mathrm{Cd}^{2+}$ was therefore between 0.001 and $0.050 \mathrm{mg} / \mathrm{L}$, with five concentrations in between. For chromium, $100 \%$ lethality occurred at a concentration of $1.0 \mathrm{mg} / \mathrm{L}$, whereas no toxicity was observed at concentrations of 0.001 , $0.005,0.01,0.02$ and $0.10 \mathrm{mg} / \mathrm{L}$. However, sub-lethal effects (clubbed tentacles) were seen at $0.20 \mathrm{mg} / \mathrm{L}$, which indicates some level of toxicity. The final concentration range defined for the final acute toxicity experiments with $H$. viridissima for $\mathrm{Cr}^{6+}$ was therefore between 0.20 and $1.0 \mathrm{mg} / \mathrm{L}$, with five concentrations in between. Zinc ${ }^{2+}$ preliminary results showed that $100 \%$ lethality occurred at concentrations between 0.20 and $75.0 \mathrm{mg} / \mathrm{L}$. At concentrations between 0.02 and $0.10 \mathrm{mg} / \mathrm{L}$, the range of lethality was between $0 \%$ and $44 \%$. The final concentration range defined for the final acute toxicity experiments for $\mathrm{Zn}^{2+}$ was therefore between 0.02 and $0.50 \mathrm{mg} / \mathrm{L}$, with five concentrations in between. Preliminary results for boron showed that in the first set of experiments using a stock solution of $1 \mathrm{mg} / \mathrm{L} \mathrm{of} \mathrm{B}^{3+}$, no toxic effect was observed throughout the range of concentrations tested: 0.001 to $0.75 \mathrm{mg} / \mathrm{L}$ of $\mathrm{B}^{3+}$, with nine concentrations in between. Therefore, a new set of experiments was performed using a stock solution of $100 \mathrm{mg} / \mathrm{L}$ of $\mathrm{B}^{3+}$. In this set of experiments, $100 \%$ lethality occurred at concentrations between 50.0 and $75.0 \mathrm{mg} / \mathrm{L}$, and at concentrations of 10.0 and $25.0 \mathrm{mg} / \mathrm{L}$, lethality was $11.1 \%$ and $77.7 \%$, respectively. The final concentration range defined for the final acute toxicity experiments for $\mathrm{B}^{3+}$ was therefore between 5.0 and $75.0 \mathrm{mg} / \mathrm{L}$, with five concentrations in between.

\subsection{Results of the Final Acute Toxicity Tests for H. viridissima}

Twenty toxicity tests were performed for each of the four toxicants in order to determine their median lethal concentrations (96-h $\mathrm{LC}_{50}$ ) with $95 \%$ confidence limits for $H$. viridissima. Results showed that according to the Probit analysis, the Chi-square test for heterogeneity was not significant (the calculated Chi-square was less than the tabular value) for all the tests performed. The results of the control charts (results not shown) that were also drawn up to evaluate the sensitivity of $H$. viridissima to the four elements over the experimental period showed good repeatability: the established 95\% confidence limits described very narrow variation bands, with coefficients of variation of $32 \%$ for cadmium, $13 \%$ for chromium, $19 \%$ for zinc and $14 \%$ for boron. The sensitivity of green Hydra to cadmium chloride did not change significantly over the experimental period when used as an internal reference. The average $96-\mathrm{h} \mathrm{LC}_{50}$ values for cadmium were $0.002 \mathrm{mg} / \mathrm{L}( \pm 0.000$ S.E.), with $95 \%$ confidence limits between 0.001 and $0.003 \mathrm{mg} / \mathrm{L}$; for chromium, $0.33 \mathrm{mg} / \mathrm{L}( \pm 0.009$ S.E.), with $95 \%$ confidence limits between 0.41 and $0.25 \mathrm{mg} / \mathrm{L}$; for zinc, $0.12 \mathrm{mg} / \mathrm{L}( \pm 0.005$ S.E.), with $95 \%$ confidence intervals between 0.16 and $0.07 \mathrm{mg} / \mathrm{L}$; and for boron, $17.92 \mathrm{mg} / \mathrm{L}$ ( $\pm 0.566 \mathrm{~S} . \mathrm{E}$.), with $95 \%$ confidence intervals between 22.989 and $12.86 \mathrm{mg} / \mathrm{L}$ (Table 3 ). 
Table 3. Median lethal concentration values (96-h $\mathrm{LC}_{50}$ ), confidence intervals (95\%), variation coefficients and standard deviations (S.D.) for $H$. viridissima exposed to Cadmium, Chromium, Zinc and Boron

\begin{tabular}{|c|c|c|c|c|c|}
\hline \multirow[t]{2}{*}{ Compound } & \multirow{2}{*}{$\begin{array}{c}\text { 96-h LC } \mathrm{LC}_{50} \\
(\mathrm{mg} / \mathrm{L})\end{array}$} & \multicolumn{2}{|c|}{ 95\% Confidence Intervals } & \multirow{2}{*}{$\begin{array}{l}\text { C.V. } \\
(\%)\end{array}$} & \multirow{2}{*}{$\begin{array}{c}\text { Standard } \\
\text { Error }( \pm \text { S.E })\end{array}$} \\
\hline & & Lower Limit & Upper limit & & \\
\hline $\mathrm{Cd}^{2+}$ & $* 0.002$ & 0.001 & 0.003 & 32 & 0.000 \\
\hline $\mathrm{Cr}^{6+}$ & $* 0.329$ & 0.412 & 0.246 & 13 & 0.009 \\
\hline $\mathrm{Zn}^{2+}$ & $* 0.118$ & 0.162 & 0.074 & 19 & 0.005 \\
\hline $\mathrm{Br}^{3+}$ & $* 0.001$ & 0.000 & 0.003 & 14 & 0.566 \\
\hline
\end{tabular}

\footnotetext{
* Median lethal concentration values $\left(96-\mathrm{h} \mathrm{LC}_{50}\right.$ ) for Hydra viridissima exposed to cadmium, chromium, zinc and boron. Each data represents median lethal concentration values (96-h $\left.\mathrm{LC}_{50}\right)$ of 20 replicates.
}

\subsection{Results of the Preliminary Acute Toxicity Range-finding Test for L. sativa}

The preliminary results show that $94 \%$ inhibition occurred at concentrations of 50.0 and 75.0 $\mathrm{mg} / \mathrm{L}$, and at concentrations between 1.0 and $10.0 \mathrm{mg} / \mathrm{L}$, the percentage inhibition ranged between $24 \%$ and $73 \%$. The final concentration range defined for the final acute toxicity experiments with $L$. sativa for $\mathrm{Cd}^{2+}$ was therefore between 1.0 and $50.0 \mathrm{mg} / \mathrm{L}$, with five concentrations in between. For chromium, preliminary results showed that $73-76 \%$ inhibition occurred at concentrations between 50.0 and $75.0 \mathrm{mg} / \mathrm{L}$, and at concentrations between 5.0 and $25.0 \mathrm{mg} / \mathrm{L}$, the inhibition percentage ranged between $34 \%$ and $71 \%$. The final concentration range defined for the final acute toxicity experiments with $L$. sativa for $\mathrm{Cr}^{6+}$ was therefore between 5.0 and $75.0 \mathrm{mg} / \mathrm{L}$, with five concentrations in between. For $\mathrm{Zn}^{2+}, 82-$ $91 \%$ inhibition occurred at concentrations between 75.0 and $100.0 \mathrm{mg} / \mathrm{L}$, and at concentrations between 25 and $50 \mathrm{mg} / \mathrm{L}$, the inhibition percentage ranged between $57 \%$ and $78 \%$. The final concentration range defined for the final acute toxicity experiments with $L$. sativa for $\mathrm{Zn}^{2+}$ was therefore between 25 and $100 \mathrm{mg} / \mathrm{L}$, with four concentrations in between. For boron, 63-95\% inhibition occurred at concentrations between 75.0 and $100 \mathrm{mg} / \mathrm{L}$, and at concentrations between 25.0 and $50.0 \mathrm{mg} / \mathrm{L}$, the inhibition percentage ranged between $42 \%$ and $50 \%$. The final concentration range defined for the final acute toxicity experiments with L. sativa for $\mathrm{B}^{3+}$ was therefore between 10.0 and $75.0 \mathrm{mg} / \mathrm{L}$, with four concentrations in between.

\subsection{Results of the Final Acute Toxicity Tests for L. sativa}

Twenty toxicity tests were performed for each of the four metals in order to determine their median inhibitory concentrations $\left(120-\mathrm{h} \mathrm{IC}_{50}\right)$ for $L$. sativa with $95 \%$ confidence limits. Results showed that according to the Probit analysis, the Chi-square test for heterogeneity was not significant (the calculated Chi-square was less than the tabular value) for all the tests performed. The results of the control charts that were also drawn up to evaluate the sensitivity of L. sativa to the four elements over the experimental period showed excellent repeatability: the established 95\% confidence limits described very narrow variation bands, with coefficients of variation of: $4 \%$ for cadmium, $11 \%$ for chromium, $13 \%$ for zinc and $4 \%$ for boron. The sensitivity of $L$. sativa to cadmium chloride did not change significantly over the 
experimental period when used as an internal reference. The average $120-\mathrm{h} \mathrm{IC}_{50}$ values for cadmium were $2.59 \mathrm{mg} / \mathrm{L}$ ( \pm 0.025 S.E.), with $95 \%$ confidence limits between 2.37 and 2.82 $\mathrm{mg} / \mathrm{L}$; for chromium, $12.24 \mathrm{mg} / \mathrm{L}$ ( \pm 0.305 S.E.), with $95 \%$ confidence limits between 9.51 and $14.97 \mathrm{mg} / \mathrm{L}$; for zinc, $33.88 \mathrm{mg} / \mathrm{L}( \pm 0.99$ S.E.), with $95 \%$ confidence limits between 24.99 and $42.77 \mathrm{mg} / \mathrm{L}$; and for boron, $30.69 \mathrm{mg} / \mathrm{L}$ ( \pm 0.25 S.E.), with $95 \%$ confidence limits between 28.41 and $32.98 \mathrm{mg} / \mathrm{L}$ (Table 4).

Table 4. Median inhibitory concentration values (120-h $\left.\mathrm{IC}_{50}\right)$, confidence intervals $(95 \%)$, Variation coefficients and standard deviations (S.D.), for Lactuca sativa exposed to cadmium, chromium, zinc and boron

\begin{tabular}{|c|c|c|c|c|c|}
\hline \multirow[t]{2}{*}{ Compound } & \multirow{2}{*}{$\begin{array}{c}\text { 120-h IC } \\
(\mathrm{mg} / \mathrm{L})\end{array}$} & \multicolumn{2}{|c|}{ 95\% Confidence intervals } & \multirow{2}{*}{$\begin{array}{l}\text { C.V. } \\
(\%)\end{array}$} & \multirow{2}{*}{$\begin{array}{c}\text { Standard } \\
\text { Error }( \pm \text { S.E })\end{array}$} \\
\hline & & Lower limit & Upper limit & & \\
\hline $\mathrm{Cd}^{2+}$ & $* 2.59$ & 2.37 & 2.82 & 4 & 0.025 \\
\hline $\mathrm{Cr}^{6+}$ & $* 12.24$ & 9.51 & 14.97 & 11 & 0.305 \\
\hline $\mathrm{Zn}^{2+}$ & $* 33.88$ & 24.99 & 42.77 & 13 & 0.994 \\
\hline $\mathrm{Br}^{3+}$ & $* 30.69$ & 28.41 & 32.98 & 4 & 0.255 \\
\hline
\end{tabular}

*Median Inhibitory concentration values (120-h $\mathrm{IC}_{50}$ ) for Lactuca sativa exposed to cadmium, chromium, zinc and boron. Each data represents median lethal concentration values (120-h $\mathrm{LC}_{50}$ ) of 20 replicates.

\subsection{Comparison of Toxicity between Compounds for Hydra viridissima and Lactuca Sativa}

The 96-h mean lethal toxic concentrations $\left(\mathrm{LC}_{50}\right)$ of the chemical compounds in $H$. viridissima are shown in Figure 2. Significant differences in this parameter between the compounds used were found (one-way ANOVA, $d f=3 ; F=984.83 ; P<0.001$ ). The toxicity levels of the test metals with the least harmful first were estimated as follows: boron < chromium < zinc < cadmium. A comparison of the mean 96-h LC $_{50}$ values showed that cadmium, zinc and chromium were the most toxic compounds and boron the least to $H$. viridissima Figure 2. depicts the comparison of the 96-h mean lethal toxic concentrations (96-h $\mathrm{LC}_{50} \mathrm{~s}$ ) of cadmium, chromium, zinc and boron on $\mathrm{H}$. viridissima. Bars represent means $(n=20) \pm$ S.E. Bars sharing the same letter are not significantly different (confirmed by Tukey test). On the other hand, the 120 -h mean inhibitory toxic concentrations $\left(\mathrm{IC}_{50}\right)$ of the chemical compounds in L. sativa are shown in Fig. 3. Significant differences of this parameter were detected between the compounds (one-way ANOVA: $d f=3 ; F=778.996 ; P$ $<0.001)$. The toxicity levels of the test metals with the least harmful first were as follows: zinc $<$ boron $<$ chromium $<$ cadmium (Figure. 3 ). 


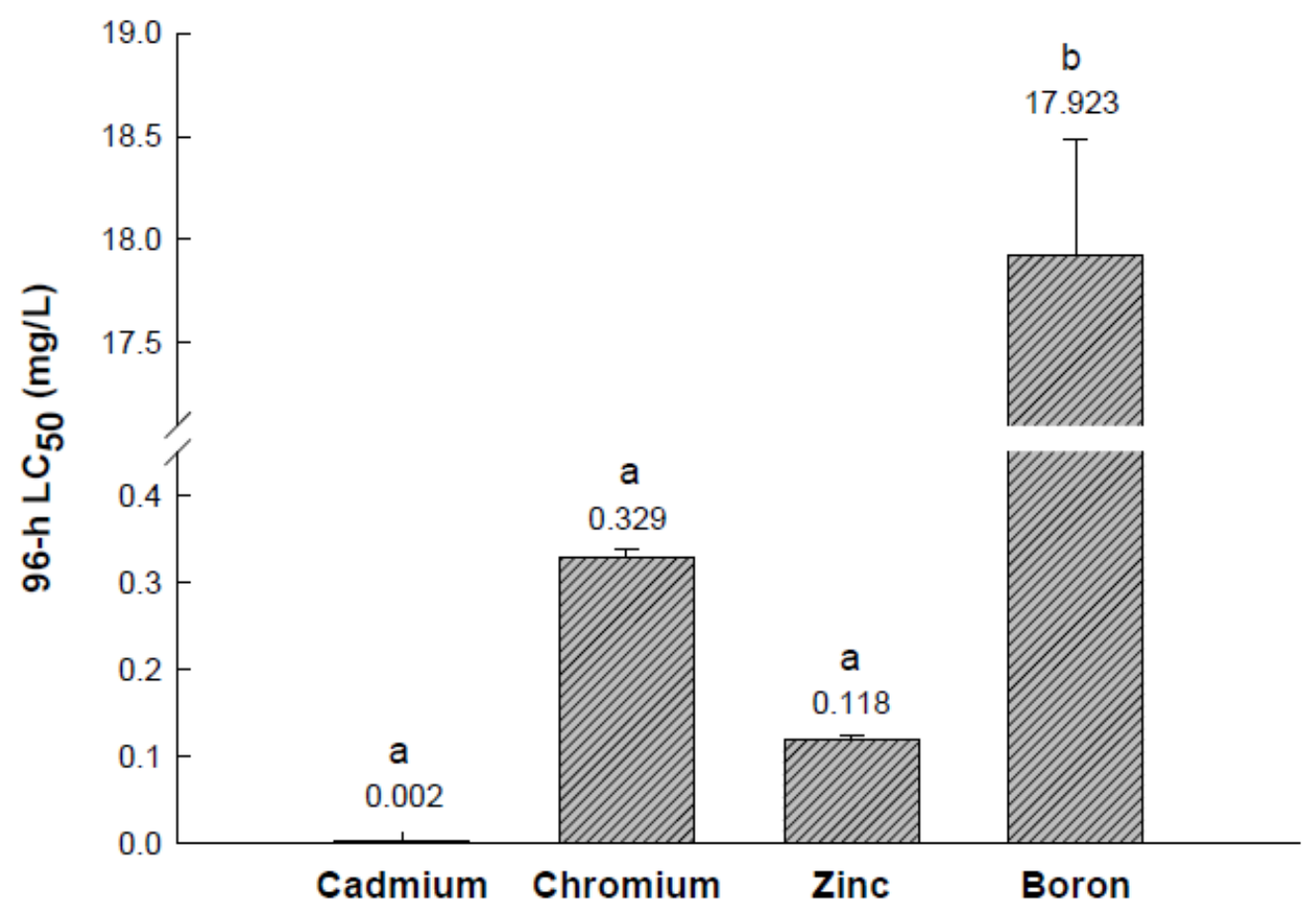

Figure 2. Comparison of the 96-h mean lethal toxic concentrations (96-h $\mathrm{LC}_{50} \mathrm{~s}$ ) of cadmium, chromium, zinc and boron on Hydra viridissima. Bars represent means $(n=20) \pm$ S.E. Bars sharing the same letter are not significantly different (confirmed by the Tukey test)

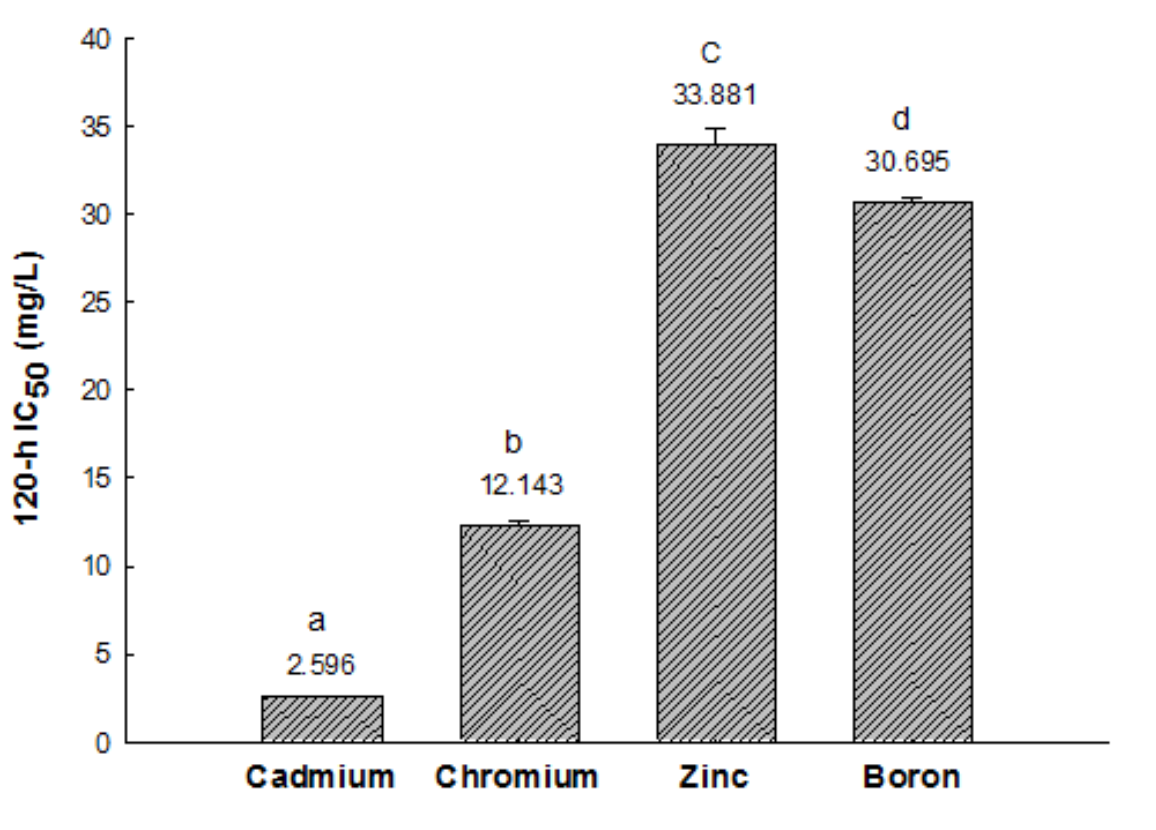

Figure 3. Comparison of the 120-h mean inhibitory toxic concentrations (120-h $\left.\mathrm{IC}_{50} \mathrm{~s}\right)$ of cadmium, chromium, zinc and boron on Lactuca sativa. Bars represent means $(n=20) \pm$ S.E. Bars with different letters indicate significant differences between compounds at $P \leq 0.05$, as determined by the Tukey test 


\section{Macrothink

\section{Discussion}

\subsection{Hydra Viridissima}

This study evaluated the potential for using green Hydra (Hydra viridissima) as a model invertebrate for an acute toxicity assessment of cadmium $\left(\mathrm{CdCl}_{2} \cdot 2 \mathrm{H}_{2} \mathrm{O}\right)$, chromium $\left(\mathrm{K}_{2} \mathrm{Cr}_{2} \mathrm{O}_{7}\right)$, zinc $\left(\mathrm{ZnSO}_{4} .7 \mathrm{H}_{2} \mathrm{O}\right)$, and boron $\left(\mathrm{H}_{3} \mathrm{BO}_{3}\right)$ - common freshwater pollutants and representative contaminants from arid regions. The sensitivity of $H$. viridissima to the tested chemical compounds for acute toxicity, with the least harmful first, was as follows: boron < chromium < zinc < cadmium. Acute toxicity endpoints with green Hydra exposed to cadmium, chromium, zinc and boron were compared with values from the literature for other species of Hydra and Daphnia magna that are usually used by regulatory agencies as toxicity indicators (Table 5). However, the variety of physicochemical conditions used for the toxicity tests (e.g., lighting, period of exposure, water characteristics) makes it difficult to compare results between studies. Moreover, the variation in Hydra responses to a specific toxicant depends on the species and the endpoints evaluated. A comparison of $96-\mathrm{h} \mathrm{LC}_{50}$ for cadmium and zinc revealed similar values to those obtained with the same toxicants by Holdway et al., (2001). Quinn et al., (2007) reported lethal $\left(\mathrm{LC}_{50}\right)$ and sublethal $\left(\mathrm{EC}_{50}\right)$ (Table 5). Endpoint values of 1.16 and $0.18 \mathrm{mg} / \mathrm{L}$ were obtained for Hydra attenuata (after $24 \mathrm{~h}$ of exposure to cadmium chloride), and of 0.167 and $0.045 \mathrm{mg} / \mathrm{L}$ (after $96 \mathrm{~h}$ of exposure). Comparing their results with the results obtained in this study, $H$. viridissima seems to be more sensitive than Hydra attenuata to the same compound. However, they used a hydra medium as a diluent to prepare the different concentrations, and in this study, hard water was used for the same purpose Table 5 . 
Table 5. Comparative toxicity data for Hydra viridissima exposed to cadmium, chromium, zinc and boron with literature values for other species of Hydra and Daphnia magna (used for regulatory testing programs as indicator of toxicity)

\begin{tabular}{|c|c|c|c|c|}
\hline Toxic & Organism & Duration (hours) & $\mathrm{LC}_{50}{ }^{\mathrm{b}}(\mathrm{mg} / \mathrm{L})$ & Reference \\
\hline \multirow[t]{5}{*}{ Cadmium } & Hydra viridissima & 96 & 0.002 & This study \\
\hline & Hydra viridissima & 96 & 0.21 & Karntanut and Pascoe, 2002 \\
\hline & Hydra viridissima & 96 & 0.003 & Holdway et al., 2001 \\
\hline & Hydra vulgaris ${ }^{a}$ & 96 & 0.16 & Karntanut and Pascoe, 2002 \\
\hline & Hydra oligatis & 96 & 0.32 & Karntanut and Pascoe, 2002 \\
\hline \multirow[t]{3}{*}{ Chromium } & Hydra attenuata & 96 & 0.17 & Quinn et al, 2007 \\
\hline & Hydra viridissima & 96 & 0.33 & This study \\
\hline & Hydra attenuata & 96 & 0.15 & Diaz-Baez and Perez, 2000 \\
\hline \multirow[t]{8}{*}{ Zinc } & Hydra viridissima & 96 & 0.19 & This study \\
\hline & Hydra viridissima & 96 & 11.0 & Karntanut and Pascoe, 2002 \\
\hline & Hydra viridissima & 96 & 2.5 & Karntanut and Pascoe, 2005 \\
\hline & Hydra viridissima & 96 & 0.93 & Holdway et al., 2001 \\
\hline & Hydra viridissima & 96 & 11.0 & Karntanut and Pascoe, 2002 \\
\hline & Hydra vulgaris ${ }^{\mathrm{a}}$ & 96 & 13.0 & Karntanut and Pascoe, 2002 \\
\hline & Hydra oligactis & 96 & 14.0 & Karntanut and Pascoe, 2002 \\
\hline & Hydra vulgari ${ }^{\mathrm{a}}$ & 96 & 2.3 & Pollino and Holdway, 1999 \\
\hline \multirow[t]{2}{*}{ Boron } & Hydra viridissima & 96 & - & This study \\
\hline & Daphnia magna & 48 & 141 & Maier and Knight, 1991 \\
\hline
\end{tabular}

${ }^{a}$ Hydra vulgaris also known as Hydra attenuata (Pollino and Holdway, 1999; Javois and Frazier-Edwards, 1991).

${ }^{\mathrm{b}}$ Median lethal concentration $\left(\mathrm{LC}_{50}\right)$.

\subsection{Other Indicators}

Furthermore, the 96-h $\mathrm{LC}_{50} \mathrm{~s}$ values for $H$. viridissima exposed to cadmium and zinc in this study were lower than reported values for other species of Hydra; these results are consistent with findings reported by Karntanut and Pascoe (2002) and Pollino and Holdway (1999). Diaz-Baez and Perez (2000) reported that the chromium 96-h $\mathrm{LC}_{50}$ value for $H$. attenuata was $0.17 \mathrm{mg} / \mathrm{L}$, whereas in this study, the $96-\mathrm{h} \mathrm{LC}_{50}$ value for $H$. viridissima was $0.329 \mathrm{mg} / \mathrm{L}$, which suggests that $H$. viridissima is less sensitive to chromium than $H$. attenuata. Information found in the literature related to Hydra and the acute toxicity of boron was too limited to enable a comparison with our results. Kot (2015) reported that negligible effects of concentrations on aquatic invertebrates were observed. These effects were in the range of 6$10 \mathrm{mg} \mathrm{B} / \mathrm{L}$ with lower values of $1-2 \mathrm{mg} / \mathrm{L}$. Negligible effects of concentrations, in the range of around $1 \mathrm{mg} / \mathrm{L}$, on fish in natural waters could be detected, although lower values have been recorded in reconstituted water. However, in this study, boron was the least toxic element for $H$. viridissma, relative to the other substances tested, with a $96-\mathrm{h} \mathrm{LC}_{50}$ value of $17.92 \mathrm{mg} / \mathrm{L}$ (Table 6). 


\section{Ml Macrothink}

Environmental Management and Sustainable Development

ISSN 2164-7682 2018, Vol. 7, No. 3

Table 6. Comparative toxicity data for Lactuca sativa exposed to cadmium, chromium, zinc and boron with literature values for L. sativa and other plant species

\begin{tabular}{|c|c|c|c|c|}
\hline Toxic & Organism & $\begin{array}{c}\text { Duration } \\
\text { (hours) }\end{array}$ & $\begin{array}{c}\mathrm{EC}_{50}{ }^{\mathrm{a}} / \mathrm{IC}_{50}{ }^{\mathrm{b}} \\
(\mathrm{mg} / \mathrm{L})\end{array}$ & Reference \\
\hline \multirow[t]{3}{*}{ Cadmium } & Lactuca sativa $\mathrm{L}$ & 120 & $2.59^{\mathrm{b}}$ & This study \\
\hline & Lactuca sativa $\mathrm{L}$. & 120 & $21.3^{\mathrm{b}}$ & Castillo et al., 2000 \\
\hline & Lepidium sativum L. & 48 & $26.5^{\mathrm{a}}$ & Montvydienė and Marčiulionienè, 2004 \\
\hline \multirow[t]{5}{*}{ Chromium } & Lactuca sativa $\mathrm{L}$. & 120 & $12.24^{\mathrm{b}}$ & This study \\
\hline & Lactuca sativa & 72 & $6.42^{a}$ & Barbero et al., 2001 \\
\hline & Cucumis sativus & 72 & $43.58^{\mathrm{a}}$ & Barbero et al., 2001 \\
\hline & Lepidium sativum $\mathrm{L}$. & 48 & $1.8^{\mathrm{a}}$ & Montvydienė and Marčiulionienė, 2004 \\
\hline & Lepidium sativum $L$. & 72 & $4.14^{\mathrm{a}}$ & Barbero et al., 2001 \\
\hline \multirow[t]{5}{*}{ Zinc } & Lactuca sativa $\mathrm{L}$ & 120 & $33.88^{\mathrm{b}}$ & This study \\
\hline & Lactuca sativa $\mathrm{L}$. & 120 & $24.48^{\mathrm{a}}$ & Bohórquez and Campos, 2007 \\
\hline & Lactuca sativa $\mathrm{L}$. & 120 & $25.2^{\mathrm{a}}$ & Diaz-Baez and Perez, 2000 \\
\hline & Lactuca sativa $\mathrm{L}$ & 120 & $28.5^{\mathrm{a}}$ & Arkhipchuk et al., 2000 \\
\hline & Lepidium sativum L. & 48 & $149^{\mathrm{a}}$ & Montvydienè and Marčiulionienè, 2004 \\
\hline \multirow[t]{4}{*}{ Zinc } & Lactuca sativa $\mathrm{L}$ & 120 & $33.88^{b}$ & This study \\
\hline & Lactuca sativa $\mathrm{L}$. & 120 & $24.48^{\mathrm{a}}$ & Bohórquez and Campos, 2007 \\
\hline & Lactuca sativa $\mathrm{L}$. & 120 & $25.2^{\mathrm{a}}$ & Diaz-Baez and Perez, 2000 \\
\hline & Lactuca sativa $\mathrm{L}$ & 120 & $28.5^{\mathrm{a}}$ & Arkhipchuk et al., 2000 \\
\hline Boron & Lactuca sativa $\mathrm{L}$ & 120 & $30.69^{b}$ & This study \\
\hline
\end{tabular}

a Median effective concentration $\left(\mathrm{EC}_{50}\right)$ : $50 \%$ effective concentration according to the inhibition of root elongation in plant species.

${ }^{\mathrm{b}}$ Median inhibitory concentration $\left(\mathrm{IC}_{50}\right)$ : $50 \%$ inhibition of root elongation.

In addition, a number of environmental factors are known to affect the results of the various toxicity tests. Holdway et al., (2001) suggested that one of the reasons for the variability in the responses of the test organisms to chemical substances reported in the literature could be due to the differences in abiotic modifying factors, such as water hardness, $\mathrm{pH}$ and temperature, used by investigators, rather than species differences. For example, Karntanut and Pascoe (2002) found that the 96-h $\mathrm{LC}_{50}$ s values of cadmium and zinc for $H$. viridissima were $0.21 \mathrm{mg} / \mathrm{L}$ and $11.0 \mathrm{mg} / \mathrm{L}$, respectively; however, their test solution was a Hydra medium, which was harder than that used in this study (total hardness $209.76 \mathrm{mg} / \mathrm{L}$ as $\mathrm{CaCO}_{3}$ compared to $170.3 \mathrm{mg} / \mathrm{L}$ as $\mathrm{CaCO}_{3}$ ), and the temperature was $20^{\circ} \mathrm{C}$ instead of $24{ }^{\circ} \mathrm{C}$; the $\mathrm{pH}$ was also higher than the $\mathrm{pH}$ used in this study: 7.89 and 7.44, respectively. Holdway et al (2001) found that the 96-h $\mathrm{LC}_{50} \mathrm{~s}$ values of both cadmium and zinc for $H$. viridissima were $0.003 \mathrm{mg} / \mathrm{L}$ and $0.93 \mathrm{mg} / \mathrm{L}$, respectively. Their findings are comparable to the $96-\mathrm{h} \mathrm{LC}_{50}$ values reported in this study for both cadmium and zinc $(0.002 \mathrm{mg} / \mathrm{L}$ and $0.12 \mathrm{mg} / \mathrm{L}$, respectively). However, their dilution medium (total hardness: $19-20 \mathrm{mg} / \mathrm{L}$ as $\mathrm{CaCO}_{3}$ ) was considerably harder than the dilution medium used in this study; $\mathrm{pH}$ and temperature were similar in both studies. 


\subsection{Lactuca Sativa L.}

This study also evaluates the potential for using L. sativa as a model plant for an acute toxicity assessment of cadmium $\left(\mathrm{CdCl}_{2} \cdot 2 \mathrm{H}_{2} \mathrm{O}\right)$, chromium $\left(\mathrm{K}_{2} \mathrm{Cr}_{2} \mathrm{O}_{7}\right)$, zinc $\left(\mathrm{ZnSO}_{4} \cdot 7 \mathrm{H}_{2} \mathrm{O}\right)$, and boron $\left(\mathrm{H}_{3} \mathrm{BO}_{3}\right)$. The sensitivity of L. sativa to the tested chemical compounds for acute toxicity, with the least harmful first, was as follows: zinc < boron < chromium < cadmium. The variety of conditions used for the toxicity tests (e.g., lighting intensity, duration of exposure, water characteristics) makes it difficult to compare results between studies. Moreover, the variation in plant responses to a specific toxicant depends on plant species and endpoints evaluated.

A comparison of the $120-\mathrm{h} \mathrm{IC}_{50}$ values of all chemical substances tested (Table 6) showed that the toxic one to L. sativa was cadmium $(2.59 \mathrm{mg} / \mathrm{L})$. The $120-\mathrm{h} \mathrm{IC}_{50}$ value for cadmium obtained in this study for L. sativa was lower than the value of $21.3 \mathrm{mg} / \mathrm{L}$ reported by Castillo et al. (2000). Nevertheless, they did not mention the dilution medium and the $\mathrm{pH}$ used in the preparation of the toxic solutions, which may contribute to the observed differences in cadmium toxicity. Montvydienè and Marčiulionienè (2004) studied the toxic interactions of heavy metals using Lepidium sativum (Brassicaceace). They reported a cadmium $\left[\mathrm{Cd}\left(\mathrm{NO}_{3}\right)_{2} .4 \mathrm{H}_{2} \mathrm{O}\right] 48-\mathrm{h} \mathrm{EC} 50$ value for the inhibition of root elongation of $26.5 \mathrm{mg} / \mathrm{L}$; in this study, the $120-\mathrm{h} \mathrm{IC}_{50}$ value for $L$. sativa was lower, suggesting that L. sativa is more sensitive to cadmium than Lepidium sativum. Ding et al., 2011; Song et al., (2015) studied the effects of cadmium toxicity in Chinese cabbage, brassica napus, youmai lettuce, mustard pakchoi and cucumber. They found that cucumbers were the most tolerant to Cd toxicity among the studied crops. In addition, they established that most of the studied crop seedlings showed cadmium toxicity symptoms with $0.1-0.25 \mathrm{mg} \times \mathrm{L}(-1)$. The $\mathrm{EC}_{20}$ (effective concentration causing a $20 \%$ inhibition of shoot biomass) values of $\mathrm{Cd}$ for the studied crops ranged from 0.03 to $24.67 \mathrm{mg} \times \mathrm{L}(-1)$. In the current report, the end point evaluated for L. sativa was $120-\mathrm{h} \mathrm{CC}_{50}$; however, it is interesting to note that most of the studied crop seedlings showed cadmium toxicity symptoms between $0.1-0.25 \mathrm{mg} \times \mathrm{L}(-1)$, and in this study, the median inhibitory concentration value was $2.59 \mathrm{mg} / \mathrm{L}$, which agrees with the assumption that $\mathrm{Cd}$ is very toxic for crop plants in the seedling stage.

The chromium $120-\mathrm{h} \mathrm{IC}_{50}$ value of $12.24 \mathrm{mg} / \mathrm{L}$ for $L$. sativa obtained in this study is comparable to the $96-\mathrm{h} \mathrm{EC}_{50}$ value of $17 \mathrm{mg} / \mathrm{L}$ reported for the inhibition of root elongation in L. sativa by Wang (1986). However, that experiment lasted four days. Munzuroglu and Geckil (2002) studied the effects of metals on seed germination, root elongation and coleoptile and hypocotyl growth in wheat (Triticum aestivum L.) and cucumber (Cucumis sativus L.). They found that the effective concentrations of metals necessary to inhibit seed germination to a certain degree increased with an increasing incubation period. Given that our experiment lasted one more day than that of Wang (1986), the longer incubation period could explain the slight differences between the results reported in this study and those of Wang's (1986) study.

The chromium 120-h $\mathrm{IC}_{50}$ value obtained for L. sativa was higher $(12.24 \mathrm{mg} / \mathrm{L})$ than the $\mathrm{EC}_{50}$ value reported for the inhibition of root elongation of L. sativa $(6.42 \mathrm{mg} / \mathrm{L})$ by Barbero et al. 
(2001). However, they used deionized water as a dilution medium. Based on water chemistry data from Barbero et al.'s (2001) study, the increased water hardness (total hardness: 170 $\mathrm{mg} / \mathrm{L}$ as $\mathrm{CaCO}_{3}$ ) in this study may have contributed to the observed differences in chromium toxicity (EPS, 1999; Holdway et al., 2001; Arkhipchuk et al., 2000). The L. sativa used in this study was more sensitive to chromium than was Cucumis sativum $\left(72-\mathrm{h} \mathrm{EC} \mathrm{E}_{50}=43.58 \mathrm{mg} / \mathrm{L}\right)$, in which inhibition of root elongation was measured by Barbero et al. (2001). However, the chromium $48-\mathrm{h} \mathrm{EC}_{50}$ and $72-\mathrm{h} \mathrm{EC}_{50}$ values $(1.8$ and $4.14 \mathrm{mg} / \mathrm{L}$, respectively) for the inhibition of root elongation in Lepidium sativum reported by Montvydienè and Marč iulionienè (2004) and Barbero et al. (2001), respectively, were lower than the results reported for L. sativa in this study.

The toxicity of zinc to $L$. sativa is shown by the $120-\mathrm{h} \mathrm{IC}_{50}$ value of $33.881 \mathrm{mg} / \mathrm{L}$. This value was comparable to other values from the literature $\left(120-\mathrm{h} \mathrm{EC}_{50}=25.2 \mathrm{mg} / \mathrm{L}\right.$ and $120-\mathrm{h} \mathrm{EC}_{50}$ $=28.5 \mathrm{mg} / \mathrm{L}$ ) reported for the inhibition of root elongation in L. sativa by Diaz-Baez and Perez (2000) and Arkhipchuk et al. (2000), respectively. Bohórquez and Campos (2007) reported a zinc value for $L$. sativa $120-\mathrm{h} \mathrm{EC}_{50}$ of $24.48 \mathrm{mg} / \mathrm{L}$. The comparison between $L$. sativa and Lepidium sativum reveals that the 48 -h (149 $\mathrm{mg} \mathrm{Zn/L)} \mathrm{EC}_{50}$ value reported for the inhibition of root elongation in Lepidium sativum by Montvydienè and Marčiulionienè (2004) is higher than the $120-\mathrm{h}(33.881 \mathrm{mg} \mathrm{Zn/L}) \mathrm{IC}_{50}$ value reported in this study. Nevertheless, the $48-\mathrm{h}(8.419 \mathrm{mg} \mathrm{Zn} / \mathrm{L}) \mathrm{EC}_{50}$ value reported for the inhibition of root elongation in Lepidium sativum by Arambasic et al. (1994) is lower than the 120-h $\mathrm{IC}_{50}$ value reported in this study. Arambasic et al., (1994) reported a zinc 48-h $\mathrm{EC}_{50}$ value for the inhibition of root elongation in Allium cepa $\mathrm{L}$. of $0.39 \mathrm{mg} / \mathrm{L}$; in this study, the $120-\mathrm{h} \mathrm{IC}_{50}$ value for L. sativa was $33.88 \mathrm{mg} / \mathrm{L}$, which suggests that $L$. sativa is less sensitive than Allium cepa $\mathrm{L}$. to zinc. The toxicity of boron to $L$. sativa is shown by the $120-\mathrm{h} \mathrm{IC}_{50}$ value of 30.69 $\mathrm{mg} / \mathrm{L}$. In general, the differences in the ratio of $\mathrm{EC} / \mathrm{IC}_{50}$ values for heavy metals depend on the plant species, duration of the experiments, and the methods used. In this study, boron toxicity was specially evaluated since B toxicity in crops is a significant problem in irrigated environments, where groundwater application contributes to the accumulation of excess B in the soil. In irrigated environments where water reuse management strategies are practiced, B toxicity may also overlap with the occurrence of saline soils, exposing crops to both stresses simultaneously. In addition, soils intrinsically high in B exist in many parts of the world, including southern Australia, West Asia and North Africa (Schnurbusch et al., 2010; Bastías et al., 2010). However, although information about B toxicity's independent effects is abundant, information about its toxic effects in L. sativa is very limited with regard to the toxicity levels and responses to them. Apostol and Zwiazek (2004) studied the effects of boron on growth, water and nutrient uptake in jack pine (Pinus banksiana). They demonstrated that high boron concentrations inhibited stomatal conductance and root water flow, and caused needle injury in jack pine seedlings.

\section{Conclusions}

The results obtained in this study suggest that the test organisms show different sensitivities to the tested heavy metals. The acute toxicity of the tested substances decreases in the following order: $\mathrm{Cd}>\mathrm{Zn}>\mathrm{Cr}>\mathrm{B}$ and $\mathrm{Cd}>\mathrm{Cr}>\mathrm{B}>\mathrm{Zn}$, for H. viridissima and L. sativa, 
respectively. There were significant acute $L$. sativa toxicity differences following exposure to the non-essential metals cadmium and chromium (Ramos et al., 2002; Ali et al., 2004) and to the essential elements zinc and boron (MacFarlane and Burchett., 2002; Çöl and Çöl., 2003). Accordingly, it would be expected that cadmium and chromium, which are non-essential elements with no known biological function, cause greater inhibitory effects at lower concentrations than zinc and boron, which are essential elements in plant growth and development. In conclusion, $H$. viridissima can be considered as a potentially useful and sensitive aquatic invertebrate model for acute toxicity testing. Though $H$. viridissima was the more sensitive indicator of toxicity for all the evaluated substances, L. sativa could also be considered a useful and sensitive vascular plant model in which to rank toxicants in order of potential hazard. Based on the results from this study and the literature review, it can be concluded that the different sensitivities of the test organisms to various pollutants, as well as the simplicity of test procedures, are the main reasons for their applicability in water toxicity assessments.

\section{Acknowledgments}

The authors would like to thank the Bonaterra Foundation for financing this research at The Albert Katz International School of Desert Studies. Thank to Prof. Eliahu Zlotkin and Daniel Sher from the Hebrew University of Jerusalem for their technical support and donation of the green Hydra that was used during this investigation. We thank Prof. Avi Golan, Prof. Zeev Ronen, Dr. Ludmila Katz and Clara Ariza for their advice and cooperation.

\section{References}

Ali, N. A., Ater, M., Sunahara, G. I., \& Robidoux, P. Y. (2004). Phytotoxicity and bioaccumulation of copper and chromium using barley (Hordeum vulgareL.) in spiked artificial and natural forest soils. Ecotoxicology and Environmental Safety, 57(3), 363-374.

https://doi.org/10.1016/S0147-6513(03)00074-5

APHA. (2012). Standard Methods for the Examination of Water and Wastewater. 22th edition, American Public Health Association, Washington DC, pp 1496.

Apostol, K. G., \& Zwiazek, J. J. (2004). Boron and water uptake in jack pine (Pinus banksiana). Environmental and Experimental Botany, 51, 145-153.

https://doi.org/10.1016/j.envexpbot.2003.09.002

Arambasic, M. B., Bjelic, S., \& Subakov, G. (1994). Acute toxicity of heavy metals (copper, lead, zinc) phenol and sodium on Allium cepa L., Lepidium sativum L. and Daphnia magna St.: Comparative investigations and the practical applications. Water Resources, 29, 497-503.

Arkhipchuk, V. V., Romanenko, V. D., Malinovskaya, M. V., Kipnis, L. S., Solomatina, V. D., \& Krot, Y. G. (2000). Toxicity assessment of water samples with a set of animal and plant bioassays: Experience of the Ukrainian participation in the WaterTox program. Environmental Toxicology, 15, 277-286.

https://doi.org/10.1002/1522-7278(2000)15:4<277::AID-TOX3>3.0.CO;2-D

Barbero P., Beltrami M., Baudo, R., \& Rossi, D. (2001). Assessment of lake sediments 
phytoxicity after the limiting treatment. Journal of Limnology, 60, 2269-2276. https://doi.org/10.4081/jlimnol.2001.1.269

Bastías, E., Alcaraz-López, C., Bonilla, I., Martínez-Ballesta, M. C., Bolaños, L., \& Carvajal, M. (2010). Interactions between salinity and boron toxicity in tomato plants involve apoplectic calcium. Journal of Plant Physiology, 167, 54-60.

https://doi.org/10.1016/j.jplph.2009.07.014

Beach, M. J., \& Pascoe, D. (1998). The role of Hydra Vulgaris (Pallas) in assessing the toxicity of freshwater pollutants. Water Research, 32, 101-106.

https://doi.org/10.1016/S0043-1354(97)00180-192

Bigalke, M., Schwab, L., Rehmus, A., Tondo, P., \& Flisch, M. (2018). Uranium in agricultural soils and drinking water wells on the Swiss Plateau. Environmental Pollution, 233, 943-951. https://doi.org/10.1016/j.envpol.2017.09.061

Blaise, C., \& Jean-Francois, F. (2005). Small scale freshwater toxicity investigation (Editors, Springer): Vol 1: toxicity test methods, p 1-68.

Bohórquez, P., \& Campos, C. (2007). Assessment of Lactuca sativa and Selenastrum capricornutum like indicators of water toxicity. Universitas Scientiarum, 12(2), 83-89.

Buchet, J. P., \& Lison, D. (2000). Clues and uncertainties in the risk assessment of arsenic in drinking water. Food and Chemical Toxicology, 38, S81-S85.

https://doi.org/10.1016/S0278-6915(99)00130-141

Butterwick, L., Oude, N., \& Raymond, K. (1989). Safety assessment of boron in aquatic and terrestrial environments. Ecotoxicology and Environmental Safety, 17, 339-371.

https://doi.org/10.1016/0147-6513(89)90055-559

Castillo, G. C., Villa, I. C., \& Neild, E. (2000). Ecotoxicity assessment of metals wastewater using multitrophic assays. Environ. Toxicol. Water Qual, 15, 370-375. https://doi.org/10.1002/1522-7278(2000)15:5<370::AID-TOX3>3.0.CO;2-S

Çöl, M., \& Çöl, C. (2003). Environmental boron contamination in waters of Hisarcik area in the Kutahya Province of Turkey. Food and Chemical Toxicology, 41, 1417-1420. https://doi.org/10.1016/S0278-6915(03)00160-171

Díaz-Baez, M. C., \& Pérez, J. B. (2000). Intra laboratory experience with a battery of bioassays: Colombia Experience. Environmental Toxicology, 15, 297-303. https://doi.org/10.1002/1522-7278(2000)15:4<297::AID-TOX5>3.0.CO;2-5

Ding, F. H., Liu, S. X. D., \& Wang, G. (2011). Different sensitivity of 23 common crop species to cadmium toxicity (in Chinese). Huan Jing Ke Xue, 32(1), 277-283.

El-Nahhal, Y. (2003). Persistence, mobility, efficacy and activity of chloroacetanilide herbicide formulation under greenhouse and field experiments. Environmental Pollution, 124, 33-38. https://doi.org/10.1016/S0269-7491(02)00431-441.

Environmental Protection Series (EPS). (1999). Environmental Technology Centre 
Environment Canada. Guidance Document on Application and Interpretation of Single-species Test in Environmental Toxicology. Report EPS 1/RM/34, 20-22.

Escoto, V., García, J. F., \& Peinado, F. M. (2007). Determination of phytotoxicity of soluble elements in soils, based on a bioassay with lettuce (Lactuca sativa L.). Science of the Total Environment, 378, 63-66. https://doi.org/10.1016/j.scitotenv.2007.01.007

Han, X-M., Hu, H-W., Shi, X-Z., Wang, J-T., Han, L-L., Chen, D., \& He, J-Z., (2016). Impacts of reclaimed wáter irrigation on soil antibiotic resístame in urban parks of Victoria, Australia. Environmental Pollution, 211, 48-57. https://doi.org/10.1016/j.envpol.2015.12.033

Holdway, D. A., Lok, K., \& Semaan, M. (2001). The acute and chronic toxicity of cadmium and zinc to two Hydra species. Environmental Toxicology, 16, 557-565.

https://doi.org/10.1002/tox.10017

Javois, L. C., \& Franzier-Edwards, A. M. (1991). Simultaneous effects of head activator on the dynamics of apical and basal regeneration in Hydra vulgaris (formerly Hydra attenuata). Developmental Biology, 144(1), 78-85. https://doi.org/10.1016/0012-1606(91)90480-Q

Karntanut, W., \& Pascoe, D. (2002). Toxicity of copper, cadmium and zinc to four different Hydra (Cnidaria: Hydrozoa). Chemosphere, 47, 1059-1064.

https://doi.org/10.1016/S0045-6535(02)00050-4

Karntanut, W., \& Pascoe, D. (2005). Effects of removing symbiotic green algae on the response of Hydra viridissima (Pallas 1776) to metals. Ecotoxicology and Environmental Safety, 60(3), 301-305. https://doi.org/10.1016/j.ecoenv.2004.04.001

Khan, K., Lu, Y., Khan, H., Ishtiaq, M., Khan, S., Waqas, M., Wei, L., \& Wang, T. (2013). Heavy metals in agricultural soils and crops and their health risks in Swat District, northern Pakistan. Food and Chemical Toxicology, 58, 449-458.

https://doi.org/10.1016/j.fct.2013.05.014

Kot, F. S. (2015), Boron in the environment: chapter 1. Faculty of Civil and Environmental Engineering, Technione Israel Institute of Technology, Haifa, Israel, p-33. https://doi.org/10.1016/B978-0-444-63454-2.00001-0

Kovačević, G., Želježić, D., Horvatin, K, \& Kalafatić, M. (2007). Morphological features and comet assay of green and brown hydra treated with aluminum. Symbiosis, 44, 145-152.

Lenhoff, H. M. (1983). Determining growth rates of groups of Hydra and budding rates in individual Hydra, P. 47-52, In Hydra: Research methods, Plenum Press, New York.

MacFarlane, G. R., \& Burchett, M. D. (2002). Toxicity, growth and accumulation relationships of copper, lead and zinc in the grey mangrove Avicennia marina (Forsk.) Vierh. Marine Environmental Research, 54, 65-84. https://doi.org/10.1016/S0141-1136(02)00095-8

Maier, K. J., \& Knight, A. W. (1991). The toxicity of waterborne boron to Daphnia magna and Chironomus decorus and the effects of water hardness and sulfate on boron toxicity. Environmental. Contam. Toxicol, 20, 282-287. https://doi.org/10.1007/BF01055917 
Mansour, S. A., \& Sidky, M. M. (2002). Ecotoxicological Studies. 3. Heavy metals contaminating water and fish from Fayoum Governorate, Egypt. Food Chemistry, 78, 15-22. https://doi.org/10.1016/S0308-8146(01)00197-2

Montvydienè, D., \& Marčiulionienè, D. (2004). Assessment of toxic interactions of heavy metals in a multicomponent mixture using Lepidium sativum and Spirodella polyrrhiza. Environmental Toxicology, 19, 351-358. https://doi.org/10.1002/tox.20041

Munzuroglu, O., \& Geckil, H. (2002). Effects on seed germination, root elongation, and coleoptile and hypocotyl growth in Triticum aestivum and Cucumis sativus. Arch. Environ. Contam. Toxicol, 43, 203-213. https://doi.org/10.1007/s00244-002-1116-1124

Murch, S. J., Haq, K., Rupasinghe, V. H. P., \&. Saxena, P. K. (2003). Nickel contamination affects growth and secondary metabolite composition of St. John's wort (Hypericum perforatum L.). Environmental and Experimental Botany, 49, 251-257. https://doi.org/10.1016/S0098-8472(02)00090-4

Murphy, F., \& Quinn, B. (2018). The effects of micro plastic on freshwater Hydra attenuata feeding morphology \& reproduction. Environmental Pollution, 234, 487-494. https://doi.org/10.1016/j.envpol.2017.11.029

Pollino, C. A., \& Holdway, D. A. (1999). Potential of two Hydra species as standard toxicity test animals. Ecotoxicology and Environmental Safety, 43, 309-316.

https://doi.org/10.1006/eesa.1999.1796

Quinn, B., Gagné, F., \& Blaise, C. (2007). Validation of a multi-well plate toxicity test to assess feeding behaviour of the cnidarian, Hydra attenuate. Fresenius Environmental Bulletin, by PSP Volume 16 - No 9a.

Ramos, I., Esteban, E., \& Lucena, J. J. A. (2002). Cadmium uptake and subcellular distribution in plants of Lactuca sp. Cd-Mn interaction. Plant Science, 162, 761-767. https://doi.org/10.1016/S0168-9452(02)00017-1

Reznik, A., Feinerman, E., Finkelshtain, I., Fisher, F., Huber-Le, A., Joyce, B., \& Kan, I. (2017). Economic implications of agricultural reuse of treated wastewater in Israel: A statewide long-term perspective. Ecological Economics, 135, 222-233.

https://doi.org/10.1016/j.ecolecon.2017.01.013

Schnurbusch, T., Hayes, J., \& Sutton, T. (2010). Review: Boron toxicity tolerance in wheat and barley: Australian perspectives. Breeding Science, 60, 297-304.

https://doi.org/10.1270/jsbbs.60.297

Sherry, J., Scott, B., \& Dutka, B. (1997). Use of varios acute, sublethal and early life-stage tests to evaluate the toxicity of refinery effluent. Environmental Toxicology and Chemistry, 16(11), 2249-2257. https://doi.org/10.1002/etc.5620161108

Song, W-E., Chen, S-H., Liu, J-F., Chen, L., Song, N-N., Li, N., \& Liu, B. (2015). Variation of $\mathrm{Cd}$ concentration in various rice cultivars and derivation of cadmium toxicity thresholds for paddy soil by species-sensitivity distribution. Journal of integrative agriculture, 14(9), 


\section{Macrothink

1845-1854. https://doi.org/10.1016/S2095-3119(14)60926-6

Taghizadeh, S. F., Davarynejad, G., Asili, J., Nemati, S. H., Rezaee, R., Goumenou, M., Tsatsakis, A. M., \& Karimi, G. (2017). Health risk assessment of heavy metals via dietary intake of five pistachio (Pistacia vera L.) cultivars collected from different geographical sites of Iran. Food and Chemical Toxicology, 74, 320-325.

https://doi.org/10.1016/j.fct.2017.06.035

Traesel, G. K., de Souza, J. C., de Barros, A. L., Marcos Alexandre Souza, M. A., Schmitz, W. O., Muzzi, R. M., Oesterreich, S. A., \& Arena, A. C. (2014). Acute and subacute (28 days) oral toxicity assessment of the oilextracted from Acrocomia aculeata pulp in rats, Food and Chemical Toxicology, 74, 320-326. https://doi.org/10.1016/j.fct.2014.10.026

U.S. Environmental Protection Agency. (2002). Methods for measuring the acute toxicity of effluents and receiving waters to freshwater and marine organisms. Fifth Edition. U.S EPA/821/R-02/012, U.S. Environmental Protection Agency, Washington, D.C.

Wang, W. (1986). Root elongation method for toxicity testing of organic and inorganic pollutants. Environ. Toxicol. Chem, 6, 409-414. https://doi.org/10.1002/etc.5620060509

\section{Copyright Disclaimer}

Copyright for this article is retained by the author(s), with first publication rights granted to the journal.

This is an open-access article distributed under the terms and conditions of the Creative Commons Attribution license (http://creativecommons.org/licenses/by/3.0/). 